\title{
Using Ki-67 Mitotic Activity Markers as a Predictor of the Progression of Adhesions in the Abdominal Cavity
}

\author{
Irina A. Shurygina, $\mathrm{PhD}, \mathrm{ScD}^{1}$; Michael G. Shurygin, $\mathrm{PhD}, \mathrm{ScD}^{1,2}$ \\ Elena E. Chepurnykh, $\mathrm{PhD}^{1}$; Nataliya I. Ayushinova, $\mathrm{PhD}, \mathrm{ScD}^{1}$ \\ ${ }^{1}$ Irkutsk Scientific Center of Surgery and Traumatology; ${ }^{2}$ Pharmasyntez \\ Irkutsk, the Russian Federation
}

\begin{abstract}
Background: Ki-67 is a nuclear protein expressed in all proliferating cells of vertebrates during mitotic cycle phases S, G1, G2, and M, except for G0. Studying this marker is widely used to diagnose the proliferative activity of tumors. However, studying Ki-67 in non-neoplastic diseases attracts much less attention among the researchers. The aim of this study was to assess the possibility of using staining for Ki-67 to identify the proliferative potential of fibroblasts during the formation of adhesions in the abdominal cavity (AC).

Methods and Results: Experiments were carried out on male Wistar rats. The adhesion process in AC was simulated in

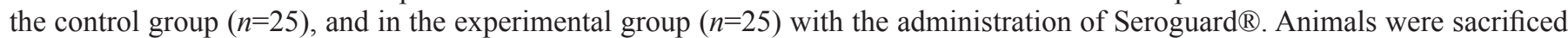
on Days 1-30, and the severity of the adhesive process in AC was assessed. Histological sections were prepared and stained for Ki-67. It was found that the animals of the control group had increased severity of the adhesive process in AC during the observation. Maximum increase in severity was registered on Day 30 - 12[9-13] points in the control group and 4[4-4] points in the experimental group $(P=0.0079)$. High proliferative activity of fibroblasts in the control group was detected on Days $3,7,14$ and 30 , which may indicate an active division of fibroblasts and the formation of adhesions in the damaged area. In the experimental group, single Ki-67 positive cells were noted during the entire observation period, which may point to a reduced potential for the formation of adhesions.

Conclusion: Our study showed the prospects of using Ki-67 staining to determine the severity of the developing adhesive process in $\mathrm{AC}$, and also revealed one of the possible mechanisms that inhibit the formation of the adhesive process when using Seroguard ${ }^{\circledR}$ - a decrease in the mitotic activity of fibroblasts in the area of peritoneal injury. (International Journal of Biomedicine. 2020;10(4):412-415.)
\end{abstract}

Key Words: adhesive process $\bullet$ mitotic activity $\bullet$ Ki-67 $\bullet$ p38 MAPK

\section{Abbreviations}

AC, abdominal cavity; mRNA, messenger ribonucleic acid; p38 MAPK, p38 mitogen-activated protein kinases.

\section{Introduction}

$\mathrm{Ki}-67$ is a nuclear protein expressed in all proliferating cells of vertebrates during mitotic cycle phases $\mathrm{S}, \mathrm{G} 1, \mathrm{G} 2$, and $\mathrm{M}$, except for $\mathrm{G} 0{ }^{(1)} \mathrm{Ki}-67$ was first identified as an antigen in the nuclei of Hodgkin's lymphoma cells. ${ }^{(2)}$ In cultured cells, Ki-67 levels are the highest in the G2 phase and in mitosis. ${ }^{(3)}$

*Corresponding author: Prof. Irina A. Shurygina, PhD, ScD. Irkutsk Scientific Center of Surgery and Traumatology. Irkutsk, the Russian Federation, E-mail: irinashurygina@gmail.com
Previously, it was thought that Ki-67 is constantly regulated and used by proteasomes in the cell nucleus. However, a pathway was recently discovered for eliminating extranuclear Ki-67, through which it is transported to the Golgi apparatus. ${ }^{(4)}$ It was shown that in normal cells Ki-67 is a late marker of entry into the cell cycle; Ki-67 mRNA fluctuated with maximum levels in G2, while Ki-67 protein levels increased throughout the cell cycle, peaking in mitosis. After exit from the cell cycle, Ki-67 expression remains at a low level, but is not detected in uncycling differentiated cells or senescent cells. ${ }^{(5)}$ 
Studying this marker is widely used to diagnose the proliferative activity of tumors, in particular, breast tumors, ${ }^{(6,7)}$ pulmonary tumors ${ }^{(8)}$ prostate tumors, ${ }^{(9)}$ renal tumors,${ }^{(10)}$ gastric tumors, ${ }^{(11)}$ and glioblastomas. ${ }^{(12,13)}$ In breast tumors, Ki-67 study is included in the diagnostic standard of morphological examination. However, studying Ki-67 in non-neoplastic diseases attracts much less attention among the researchers. P. Betz et al., ${ }^{(14)}$ when studying wounds of human skin, drew attention to the fact that fibroblasts in the wound area showed an increased number of Ki-67 positive cells, which could be detected for the first time in skin lesions with a duration of 1.5 days. Positive results were consistently detected from 6 days to 1.5 months after the wounding. Only in the scar tissue of the oldest (7 months) wound, positively stained fibroblasts were not detected.

In several researches, studying $\mathrm{Ki}-67$ expression is used to assess the activity of fibrosis formation and the effectiveness of treatment, in particular, in idiopathic pulmonary fibrosis, ${ }^{(15)}$ peripheral arterial restenosis, ${ }^{(16)}$ rheumatoid arthritis, ${ }^{(17)}$ systemic sclerosis, ${ }^{(18)}$ leiomyoma of the body of the uterus and adenomyosis. ${ }^{(19)}$

El-Zammar et al. ${ }^{(20)}$ registered low proliferative activity of fibroblasts in keloid scars using the Ki-67 marker. The same observation was made in hereditary gingival fibromatosis ${ }^{(21)}$ and lipofibromatosis. ${ }^{(22)}$

The Ki-67 marker is also used to assess the proliferative activity of cells in experimental studies. ${ }^{(23-25)}$ It has been shown that $\mathrm{Ki}-67$ is not expressed in mature adhesions in AC. ${ }^{(26)} \mathrm{At}$ the same time, Ki-67 stained cells were not detected at all in peritoneal tissue samples from patients without adhesions. ${ }^{(27)}$

The aim of this study was to assess the possibility of using staining for $\mathrm{Ki}-67$ to identify the proliferative potential of fibroblasts during the formation of adhesions in the abdominal cavity (AC).

\section{Materials and Methods}

The experiments were carried out in 50 male Wistar rats. The adhesion process in $\mathrm{AC}$ was simulated by our own method, which is described in detail in patent RU 2467401. ${ }^{(28)}$

The studies were carried out in two groups: Group 1 (control group, $\mathrm{n}=25)$ - modeling the adhesive process; Group 2 (experimental group, $\mathrm{n}=25$ ) - modeling the adhesive process with administration of Seroguard $\AA$ (conjugate the 4-[4-(4-fluorophenyl)-2-(4-methylsulfylphenyl)-1H-imidazole5-pyridine with poly-1-vinylimidazole, JSC Pharmasyntez), $3 \mathrm{ml}$ during the completion of the operation. ${ }^{(29)}$

The animals were sacrificed on Days 1, 3, 7, 14, and 30. The severity of the adhesive process in $\mathrm{AC}$ was assessed using our own scale. ${ }^{(30)}$ The material from the adhesion formation zone was fixed using FineFix solution (Milestone, Italy); preparation and paraffin embedding were carried out according to the classical method. ${ }^{(31)}$

Sections were prepared and stained by the immunofluorescence method. ${ }^{(32-34)}$ Antibodies to Ki-67 rabbit polyclonal (Abbiotec, Cat. N 250733, Lot 09092202) in a dilution of 1:300 were used as primary antibodies; Alexa fluor 568 goat anti-rabbit IgG $(\mathrm{H}+\mathrm{L})$ (Invitrogen, Cat. N A-11036
Lot 757102) in a dilution of 1:300 were used as secondary antibodies. Nuclei were stained with Hoechst 33342 (Molecular Probes).

The percentage of positively stained cells on the histological specimen was calculated. During statistical processing, the median, $25 \%$ and $75 \%$ quartiles were determined.

The experiments were performed in accordance with the norms for the humane treatment of animals and approved by the Ethics Committee of the Irkutsk Scientific Center of Surgery and Traumatology.

\section{Results}

At the first stage of the study, we carried out a point assessment of the severity of the adhesive process in AC. As a result, we found that in Group 1 there was an increase in the severity of the adhesive process during the observation, and maximum increase in the severity was registered on Day 30 - 12[9-13] points out of 16 possible points according to score scale (Figure 1). In Group 2, there was no significant increase in the severity of the adhesive process; by Day 30 it was estimated at 4[4-4] points (Figure 2). Differences in the severity of the adhesive process between the groups are significant on Days 7, 14 and 30: on Day 7 in Group 1, the score was 9[8-12] points, in Group $2-4[4-6]$ points $(P=0.0159)$; on Day $14-9[6-9]$ and 3[3-4] points, respectively $(P=0.0159)$. The differences between the groups increased to Day 30 - up to $12[9-13]$ and $4[4-4]$ points $(P=0.0079)$.

To study the mitotic activity of cells in the zone of adhesion formation, we used staining for Ki-67 antigen, a marker of cell proliferation. One day after modeling the adhesive process in Group 1, only single Ki-67 positive cells were noted; in Group 2 such cells were not detected at the same timepoint.

The study carried out on Day 3, corresponding to the start of the fibroblastic phase of inflammation in animals of Group 1, showed the maximum number of Ki-67 positive cells $-18[5-28] \%$, which indicates a high proliferative potential of cells in the damaged zone. Morphologically, these cells correspond to fibroblasts of young connective tissue (Figure 3). High proliferative activity persisted in Group 1 on Days 7 $(7[5-7] \%), 14(10[8-15] \%)$, and $30(12[6-18.5] \%)$, which may indicate the continuation of active division of fibroblasts and adhesion formation in the damaged area (Figure 1).

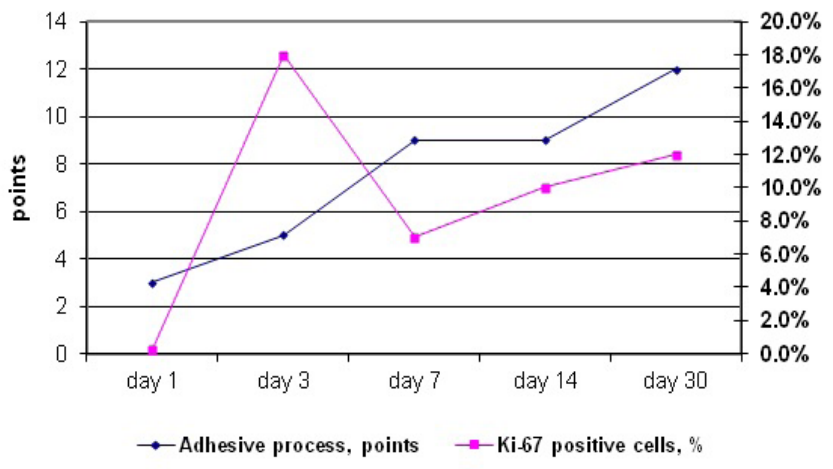

Fig. 1. Adhesion and Ki67 expression in the control group. 
In Group 2, during the entire observation period, single Ki-67 positive cells were noted (on Day $3-0[0-0]$, Day $7-$ $0[0-1]$, Day $14-0[0-1]$, and Day $30-1[0-2.5])$, which may be evidence of a reduced proliferative activity of fibroblasts in the peritoneal injury zone and reflect a reduced potential for adhesion formation (Figures 2,3).

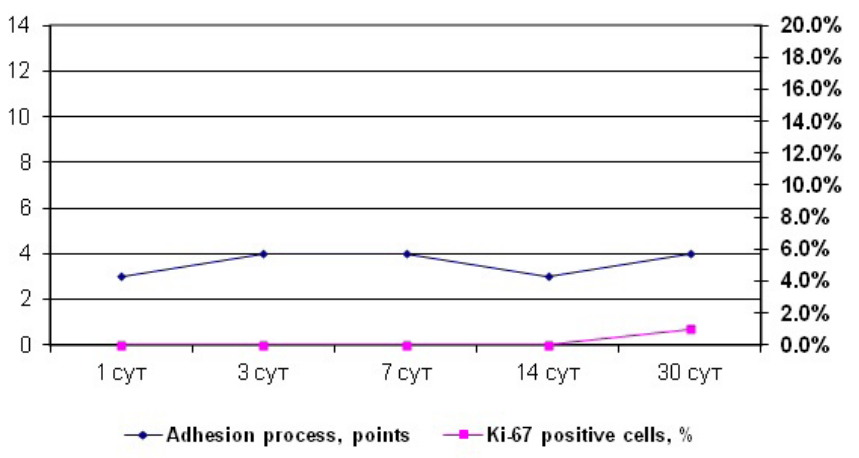

Fig. 2. Adhesion and Ki67 expression in the experimental group.

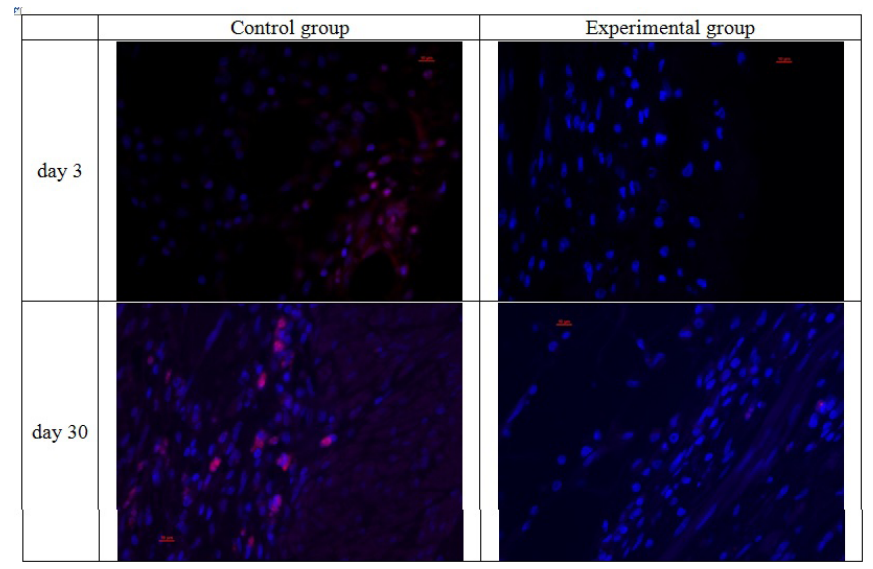

Fig. 3. Staining for Ki-67, immunofluorescence, primary antibodies to Ki-67 (Abbiotec), 1:300, secondary antibodies Alexa Fluor 568, Hoechst 33342.

Comparison of the dynamics of the formation of the adhesive process in the studied groups is shown in Figures 1, 2. Differences between the groups are significant on Days 3, 7, 14 , and 30 of observation.

\section{Discussion}

We have clearly demonstrated that positive staining of fibroblast nuclei for $\mathrm{Ki}-67$ in the area of peritoneal injury is a predictor for the severity of adhesion in AC. This observation is confirmed by the high level of Ki-67 positive cells in the control group, where the formation of the adhesive process is observed in dynamics - 12 points, which corresponds to Grade 3 according to the scale. ${ }^{(35)}$ At the same time, a low index for cells with a Ki-67 positive phenotype in the experimental group causes the formation of a Grade 1 adhesion process, estimated at 4 points. This observation of low activity of mitotic processes in fibroblasts in the repair zone when using p38 MAPK blockers (experimental group) is combined in this group with an increase in apoptosis processes, ${ }^{(36)}$ which together determines a low potential for adhesion formation.

\section{Conclusion}

Our study showed the prospects of using Ki-67 staining to determine the severity of the developing adhesive process in $\mathrm{AC}$, and also revealed one of the possible mechanisms that inhibit the formation of the adhesive process when using Seroguard $\mathbb{R}$ - a decrease in the mitotic activity of fibroblasts in the area of peritoneal injury.

\section{Competing Interests} interests.

The authors declare that they have no competing

\section{References}

1. Vashchenko LN, Karnaukhov NS, Gudtskova TN, Kvarchiya MV. [Comparison of the expression level of proliferation markers $\mathrm{Ki}-67$ and cyclin D1 in triple negative breast cancer with different androgenic status]. Sovremennye Problemy Nauki i Obrazovaniya. 2018;4:146.[Article in Russian].

2. Gerdes J, Schwab U, Lemke H, Stein H. Production of a mouse monoclonal antibody reactive with a human nuclear antigen associated with cell proliferation. Int $\mathrm{J}$ Cancer. 1983;31:13-20. doi: 10.1002/ijc.2910310104.

3. Endl E, Gerdes J. The Ki-67 protein: fascinating forms and an unknown function. Exp Cell Res. 2000;257(2):231237. doi: 10.1006/excr.2000.4888.

4. Chierico L, Rizzello L, Guan L, Joseph AS, Lewis A, Battaglia G. The role of the two splice variants and extranuclear pathway on $\mathrm{Ki}-67$ regulation in non-cancer and cancer cells. PLoS One. 2017;12(2):e0171815. doi: 10.1371/ journal.pone.0171815.

5. Sobecki M, Mrouj K, Colinge J, Gerbe F, Jay P, Krasinska L, et al. Cell-cycle regulation accounts for variability in Ki-67 expression levels. Cancer Res. 2017;77(10):2722-2734. doi: 10.1158/0008-5472.CAN-16-0707.

6. Chen X, He C, Han D, Zhou M, Wang Q, Tian J, et al. The predictive value of Ki-67 before neoadjuvant chemotherapy for breast cancer: a systematic review and meta-analysis. Future Oncol. 2017;13(9):843-857. doi: 10.2217/fon-20160420 .

7. Tagliafico AS, Bignotti B, Rossi F, Matos J, Calabrese M, Valdora F, Houssami N. Breast cancer Ki-67 expression prediction by digital breast tomosynthesis radiomics features. Eur Radiol Exp. 2019;3(1):36. doi: 10.1186/s41747-0190117-2.

8. Folescu R, Levai CM, Grigoraş ML, Arghirescu TS, Talpoş IC, Gîndac CM, et al. Expression and significance of Ki67 in lung cancer. Rom J Morphol Embryol. 2018;59(1):227-233. 9. Berlin A, Castro-Mesta JF, Rodriguez-Romo L, HernandezBarajas D, González-Guerrero JF, Rodríguez-Fernández IA, et al. Prognostic role of Ki-67 score in localized prostate cancer: A systematic review and meta-analysis. Urol Oncol. 2017;35(8):499-506. doi: 10.1016/j.urolonc.2017.05.004.

10. Menon SS, Guruvayoorappan C, Sakthivel KM, Rasmi RR. Ki-67 protein as a tumour proliferation marker. Clin 
Chim Acta. 2019;491:39-45. doi: 10.1016/j.cca.2019.01.011. 11. Seo SH, Kim KH, Oh SH, Choi Y, Ahn KJ, Lee JY, et al. $\mathrm{Ki}-67$ labeling index as a prognostic marker in advanced stomach cancer. Ann Surg Treat Res. 2019;96(1):27-33. doi: 10.4174/astr.2019.96.1.27.

12. Alkhaibary A, Alassiri AH, AlSufiani F, Alharbi MA. Ki-67 labeling index in glioblastoma; does it really matter? Hematol Oncol Stem Cell Ther. 2019;12(2):82-88. doi: 10.1016/j.hemonc.2018.11.001.

13. Wong E, Nahar N, Hau E, Varikatt W, Gebski V, Ng T, et al. Cut-point for Ki-67 proliferation index as a prognostic marker for glioblastoma. Asia Pac J Clin Oncol. 2019;15(1):59. doi: 10.1111/ajco.12826.

14. Betz P, Nerlich A, Wilske J, Tübel J, Penning R, Eisenmenger W. The time-dependent localization of $\mathrm{Ki} 67$ antigen-positive cells in human skin wounds. Int J Legal Med. 1993;106(1):35-40. doi: 10.1007/BF01225022.

15. Ronan N, Bennett DM, Khan KA, McCarthy Y, Dahly D, Bourke L, et al. Tissue and Bronchoalveolar Lavage Biomarkers in Idiopathic Pulmonary Fibrosis Patients on Pirfenidone. Lung. 2018 Oct;196(5):543-552. doi: 10.1007/ s00408-018-0140-8.

16. Krishnan P, Purushothaman KR, Purushothaman M, Turnbull IC, Tarricone A, Vasquez M, etal. Enhanced neointimal fibroblast, myofibroblast content and altered extracellular matrix composition: Implications in the progression of human peripheral artery restenosis. Atherosclerosis. 2016;251:226233. doi: 10.1016/j.atherosclerosis.2016.06.046.

17. Berger I, Weckauf H, Helmchen B, Ehemann V, Penzel R, Fink B, et al. Rheumatoid arthritis and pigmented villonodular synovitis: comparative analysis of cell polyploidy, cell cycle phases and expression of macrophage and fibroblast markers in proliferating synovial cells. Histopathology. 2005;46(5):490497. doi: 10.1111/j.1365-2559.2005.01959.x.

18. Dumoitier N, Chaigne B, Régent A, Lofek S, Mhibik M, Dorfmüller P, et al. Scleroderma peripheral B lymphocytes secrete interleukin-6 and transforming growth factor $\beta$ and activate fibroblasts. Arthritis Rheumatol. 2017;69(5):10781089. doi: 10.1002/art.40016.

19. Davydov DA, Mavricheva LA, Cherstvyi ED. [Immunohistochemical characteristics of $\mathrm{Ki}-67$ proliferation marker expression in combination of uterine leiomyoma with adenomyosis]. Meditsinskiy zhurnal. 2016;1(55):92-96. [Article in Russian].

20. El-Zammar O, Rosenbaum P, Katzenstein ALA. Proliferative activity in fibrosing lung diseases: a comparative study of Ki-67 immunoreactivity in diffuse alveolar damage, bronchiolitis obliterans-organizing pneumonia, and usual interstitial pneumonia. Hum Pathol. 2009;40(8):1182-1188. doi: 10.1016/j.humpath.2009.01.006.

21. Saygun I, Ozdemir A, Günhan O, Aydintuğ YS, Karslioğlu Y. Hereditary gingival fibromatosis and expression of Ki-67 antigen: a case report. J Periodontol. 2003;74(6):873878. doi: 10.1902/jop.2003.74.6.873.

22. Lao QY, Sun M, Yu L, Wang J. Lipofibromatosis: a clinicopathological analysis of eight cases. Zhonghua Bing Li Xue Za Zhi. 2018;47(3):186-191. doi: 10.3760/cma.j.is sn.0529-5807.2018.03.008.

23. Canbeyli ID, Akgun RC, Sahin O, Terzi A, Tuncay IC. Platelet-rich plasma decreases fibroblastic activity and woven bone formation with no significant immunohistochemical effect on long-bone healing: An experimental animal study with radiological outcomes. J
Orthop Surg (Hong Kong). 2018;26(3):2309499018802491. doi: $10.1177 / 2309499018802491$.

24. Hernández-Rangel A, Silva-Bermudez P, EspañaSánchez BL, Luna-Hernández E, Almaguer-Flores A, Ibarra C, et al. Fabrication and in vitro behavior of dual-function chitosan/silver nanocomposites for potential wound dressing applications. Mater Sci Eng C Mater Biol Appl. 2019;94:750765. doi: 10.1016/j.msec.2018.10.012.

25. Wang H, Zhao Z, Lin M, Groban L. Activation of GPR30 inhibits cardiac fibroblast proliferation. Mol. Cell Biochem. 2015;405(1-2):135-48. doi: 10.1007/s11010-015-2405-3.

26. Binnebösel M, Klinge U, Rosch R, Junge K, LynenJansen P, Schumpelick V. Morphology, quality, and composition in mature human peritoneal adhesions. Langenbecks Arch Surg. 2008;393(1):59-66. doi: 10.1007/s00423-007-0198-x.

27. Kondratovich LM, Kozachenko AV, Kogan EA, Fayzullina NM, Adamyan LV. [Clinical and morphological features of the adhesive process in patients with uterine myoma]. Akusherstvo i Ginekologiya. 2014;8:71-75. [Article in Russian].

28. Ayushinova NI, Lepekhova SA, Shurygina IA, Roy TA, Shurygin MG, Zaritskaya LV, Goldberg OA. A method for modeling the adhesions in the abdominal cavity. Patent RU 2467401 C1, d.d. 20.11.2012. Application N 2011131678/14, d.d. 27.07.2011. [In Russian].

29. Shurygina IA, Ayushinova NI, Chepurnykh EE, Shurygin MG. [Method for the prevention of adhesions of the abdominal cavity]. Eksperimentalnaya i Klinicheskaya Gastroenterologiya. 2017;10(146):83-87. [Article in Russian]. 30. Ayushinova NI, Shurygina IA, Shurygin MG, Lepekhova SA, Balykina AV, Malgataeva ER, et al. [Experimental model for the development of methods for the prevention of adhesions in the abdominal cavity]. Sibirskiy Meditsinskiy Zhurnal (Irkutsk). 2012;109(2):51-53. [Article in Russian].

31. Bancroft JD, Gamble M. Theory and practice of histological techniques. Elsevier Health Sciences, 2008.

32. Shurygin MG, Shurygina IA, Dremina NN, Kanya OV. Endogenous progenitors as the source of cell material for ischemic damage repair in experimental myocardial infarction under conditions of changed concentration of vascular endothelial growth factor. Bull Exp Biol Med. 2015;158(4):528-31. doi: 10.1007/s10517-015-2801-4.

33. Shurygina IA, Shurygin MG, Granina GB, Zelenin NV. Application of mitogen-activated protein kinase inhibitor SP 600125 for wound healing control. Journal of Regenerative Medicine \& Tissue Engineering. 2013;2. doi: http://dx.doi. org/10.7243/2050-1218-2-9.

34. Shurygin MG, Shurygina IA, Kanya OV, Dremina NN, Lushnikova EL, Nepomnyashchikh RD. Morphological evaluation of oxidative phosphorylation system in myocardial infarction under conditions of modified vascular endothelial growth factor concentration. Bull Exp Biol Med. 2015;159(3):402-5. doi: 10.1007/s10517-015-2974-x.

35. Ayushinova NI, Shurygina IA, Grigoryev EG. [The scale for assessing the severity of the adhesions of the abdominal cavity]. Acta Biomedica Scientifica. 2017;6(118):96-99. doi: 10.12737/ article_5a0a891f132b26.07816727. [Article in Russian].

36. Shurygina IA, Aushinova NI, Shurygin MG. Effect of p38 MAPK inhibition on apoptosis marker expression in the process of peritoneal adhesion formation. International Journal of Biomedicine. 2018; 8(4): 342-346. doi: 10.21103/ Article8(4)_OA15. 